\title{
Lukasz Jurek
}

Uniwersytet Ekonomiczny we Wrocławiu

\section{OTYŁOŚĆ JAKO WYZWANIE DLA POLITYKI SPOLECZNEJ W XXI WIEKU}

\begin{abstract}
Streszczenie: Współcześnie jesteśmy świadkami zasadniczej zmiany w rzeczywistości społecznej. Systematycznie zanika tradycyjny problem, jakim jest głód, a jego miejsce zajmuje nowy problem - otyłość. Już dziś otyłość uznaje się za kwestię globalną i ogólnospołeczną. Skala tego problemu stała się tak duża, że Światowa Organizacja Zdrowia (WHO) zaczęła mówić o ogólnoświatowej epidemii otyłości. Głównym celem artykułu jest przedstawienie otyłości jako priorytetowego wyzwania dla nowoczesnej polityki społecznej. Poszukiwane są w nim odpowiedzi na następujące pytania badawcze. Jaka jest istota i skala występowania otyłości? Jakie są konsekwencje społeczno-ekonomiczne otyłości? Jakie inicjatywy podejmowane są na rzecz walki z otyłością? Metoda badawcza zastosowana w artykule to analiza danych zastanych, a konkretnie: badania literaturowe, badania aktów prawnych oraz analiza danych statystycznych.
\end{abstract}

Słowa kluczowe: głód, otyłość, polityka społeczna, ubóstwo.

DOI: $10.15611 /$ eis.2014.1.05

\section{Wstęp}

Przez dominującą część historii ludzkości głód był jednym z najbardziej dotkliwych problemów społecznych. Spożywanie niedostatecznej ilości pożywienia prowadziło do degradacji biologicznej organizmu, a w skrajnych przypadkach nawet do śmierci. Problem ten był absolutnie powszechny. Co prawda, w czasach względnego dobrobytu chroniczne i ostre niedożywienie doskwierało jedynie osobom ubogim, jednakże cyklicznie (co kilka lat) powtarzały się tzw. klęski głodu, które dotykały ogółu społeczeństwa ${ }^{1}$. Zmianę pod tym względem przyniosła dopiero rewolucja przemysłowa. Zapoczątkowała ona proces intensywnych zmian cywilizacyjnych, w wyniku których żywność - dotychczas mocno ograniczona - stała się relatywnie łatwo dostępna dla całego społeczeństwa. $Z$ jednej strony był to efekt rozwoju gospodarczego (wzrostu efektywności i umasowienia produkcji dóbr, zwłaszcza artykułów

\footnotetext{
${ }^{1}$ A. Sauvy, Granice życia ludzkiego, PWN, Warszawa 1963, s. 32.
} 
rolno-spożywczych), z drugiej - rozwoju społecznego (wdrożenia zasad i narzędzi względnie sprawiedliwego podziału wytwarzanych dóbr). W ten sposób udało się zasadniczo zmniejszyć odsetek ludności cierpiącej z powodu chronicznego niedożywienia, a klęski głodu zostały praktycznie wyeliminowane.

Przezwyciężenie głodu to niewątpliwie jeden z największych sukcesów współczesnej cywilizacji. Byt człowieka uległ zdecydowanej poprawie. Przede wszystkim polepszyła się kondycja biologiczna organizmu: zwiększył się rozmiar ludzkiego ciała (masa, wysokość), organizm stał się silniejszy i bardziej odporny na schorzenia zakaźne, zwiększyła się wydolność i trwałość poszczególnych organów wewnętrznych, spowolniony został proces biologicznego starzenia ${ }^{2}$. Niestety, jak to często bywa, rozwiązanie jednego problemu stworzyło przestrzeń dla rozwoju nowego, diametralnie innego, acz równie poważnego. Tania i ogólnie dostępna żywność okazała sie niskiej jakości, przez co zaczęła zakłócać prawidłowy rozwój biologiczny organizmu, a konkretniej rzecz ujmując: zaczęła powodować otyłość. Doszło zatem do swoistego paradoksu polegającego na tym, że niski status socjoekonomiczny przestał być ryzykiem chronicznego niedożywienia, a stał się ryzykiem otyłości³.

Otaczająca nas rzeczywistość zmienia się diametralnie. Jednym z przejawów tej zmiany jest właśnie systematyczny zanik „tradycyjnego” problemu społecznego, jakim jest głód, i równoczesne rozprzestrzenianie się „nowoczesnego” problemu społecznego, jakim jest otyłość. Szacuje się, że tylko w ciągu ostatnich trzech dekad odsetek ludzi cierpiących głód zmniejszył się prawie o połowę, podczas gdy odsetek ludzi otyłych zwiększył się dwukrotnie. Już obecnie na świecie żyje więcej ludzi otyłych (ok. $1 \mathrm{mld}$ ) niż ludzi chronicznie niedożywionych (ok. $800 \mathrm{mln})^{4}$. Otyłość stała się kwestią globalną i ogólnospołeczną. Występuje w krajach zarówno biednych, jak i bogatych. Dotyka (w mniejszym lub większym stopniu) wszystkie kategorie społeczno-ekonomiczne. U progu XXI wieku skala problemu stała się tak duża, że Światowa Organizacja Zdrowia (WHO) zaczęła mówić o ogólnoświatowej epidemii otyłości.

W Polsce wciąż pokutuje błędne przekonanie, że głód jest jednym z najważniejszych problemów społecznych. Takie przekonanie jest źródłem wielu nieporozumień, które ostatnimi czasy pojawiły się w debacie publicznej. Przypomnijmy, że impulsem, który uruchomił tę debatę, była publikacja reportu Polskiej Fundacji Pomocy Dzieciom „Maciuś” pt. Głód i niedożywienie dzieci w Polsce - raport z badania ilościowego, luty 2013 r. Przedstawiono tam wyniki badań, na podstawie których wyciągnięto wniosek, że skala problemu niedożywienia dzieci w Polsce jest bardzo

${ }^{2}$ R. Fogel, D. Costa, A theory of technophysio evolution, with some implication for forecasting population, health care, and pension costs, „Demography” 1997, nr 34, s. 49-66.

${ }^{3}$ Badania amerykańskie dowodzą, że ryzyko otyłości jest o ok. 50\% większe wśród osób ubogich niż w przypadku osób nieubogich. R.A. Miech, S.K. Kumanyika, N. Stettler, B.G. Link, J.C. Phelan, V.W. Change, Trends in the association of poverty with overweight among US adolescents, 1971-2004, "JAMA" 2006, nr 295, s. 2385-2393.

${ }^{4}$ M.F. Guillén, E. Ontiveros, Global Turning Points. Understanding the Challenges for Business in the 21st Century, Cambridge University Press, New York 2012, s. 52. 
duża - znacznie większa niż w przeszłości - i wciąż się powiększa. Z taką opinią nie sposób się zgodzić. Oczywiście nie ulega wątpliwości, że głód jest wciąż obecny, zwłaszcza wśród dzieci, niemniej jednak skala i dotkliwość tego problemu systematycznie maleją ${ }^{5}$. Coraz częściej osobom ubogim nie doskwiera brak żywności, lecz borykają się one z ograniczonym dostępem do żywności o wysokiej jakości.

Głównym celem niniejszego artykułu jest przedstawienie otyłości jako priorytetowego wyzwania dla nowoczesnej polityki społecznej. Tak sformułowany cel główny można podzielić na trzy cele szczegółowe: (1) określenie istoty i skali występowania otyłości na świecie i w Polsce, (2) zdiagnozowanie negatywnych konsekwencji społeczno-ekonomicznych otyłości i (3) przedstawienie inicjatyw podejmowanych na rzecz przeciwdziałania temu problemowi.

Artykuł ma charakter poglądowy. Zastosowana metoda badawcza to analiza danych zastanych, a konkretnie: badania literaturowe, badania aktów prawnych oraz analiza danych statystycznych.

\section{Otyłość: istota i skala zjawiska}

Otyłość najogólniej można zdefiniować jako ogólnoustrojową, przewlekłą chorobę metaboliczną, wynikającą z zaburzenia równowagi między poborem a wydatkowaniem energii, która objawia się zwiększeniem ilości tkanki tłuszczowej w organizmie ${ }^{6}$.

Ilość tkanki tłuszczowej w organizmie może być oceniana różnymi metodami. Najprostsza i najpowszechniej stosowana jest metoda pośredniego pomiaru, bazująca na wskaźniku BMI (Body Mass Index). Jest on obliczany przez podzielenie masy ciała (w kg) przez kwadrat jego wysokości (w m). I tak o normalnej wadze można mówić wówczas, gdy BMI mieści się w przedziale od 18,5 do 24,9 kg/m². Gdy jego wartość zawiera się w przedziale $25-29,9 \mathrm{~kg} / \mathrm{m}^{2}$, wówczas mówimy o nadwadze, a gdy jego wartość jest większa od $30 \mathrm{~kg} / \mathrm{m}^{2}$, wówczas mamy do czynienia z otyłością. Dodatkowo otyłość jest stopniowalna: I stopnia (30-34,9 kg/m²), II stopnia $\left(35-39,9 \mathrm{~kg} / \mathrm{m}^{2}\right)$ i III stopnia (pow. $\left.40 \mathrm{~kg} / \mathrm{m}^{2}\right)^{7}$.

Poszczególne kraje zasadniczo różnią się między sobą, jeśli chodzi o udział osób otyłych w ogólnej liczbie ludności. Generalnie odsetek ten waha się od około 3\% (Indie, Indonezja, Chiny, Korea Płd., Japonia) do około 30\% (Meksyk, USA) ${ }^{8}$. Zdecydowanie skrajnymi przypadkami, jeśli chodzi o „najbardziej otyłe społeczeństwa”, są Toga, gdzie odsetek otyłych kobiet wynosi aż 70,3\%, a także Nuru, gdzie

\footnotetext{
${ }^{5} \mathrm{Na}$ generalną poprawę w zakresie zaspokojenia potrzeb żywnościowych wskazują m.in. autorzy Diagnozy społecznej. Por. T. Panek, J. Czapiński, Wyżywienie, [w:] J. Czapiński, T. Panek (red.), Diagnoza społeczna, Rada Monitoringu Społecznego, Warszawa 2013, s. 54.

${ }^{6} \mathrm{~J}$. Osiecka-Chojnacka, Epidemia otyłości a interwencja władz publicznych, „Infos: zagadnienia społeczno-gospodarcze”, nr 3(17), Biuro Analiz Sejmowych, Warszawa 2012, s. 1.

${ }^{7}$ M. Szymocha, M. Bryła, I. Maniecka-Bryła, Epidemia otyłości w XXI wieku, „Zdrowie Publiczne” 2009, nr 119(2), s. 209.

${ }^{8}$ OECD Health Data 2011, http://dx.doi.org/10.1787/888932523956 [dostęp: 12.08.2013].
} 
Tabela 1. Odsetek osób otyłych w krajach Unii Europejskiej - dorośli i piętnastolatkowie w 2011 r. (w \%)

\begin{tabular}{|c|c|c|c|c|c|}
\hline \multirow{2}{*}{ Kraj } & \multicolumn{3}{|c|}{ Dorośli } & \multicolumn{2}{|c|}{ Piętnastolatkowie } \\
\hline & ogółem & kobiety & mężczyźni & dziewczynki & chłopcy \\
\hline Rumunia & 7,9 & 8,0 & 7,6 & 8 & 20 \\
\hline Włochy & 10,3 & 9,6 & 11,1 & 11 & 22 \\
\hline Holandia & 11,4 & 12,6 & 10,2 & 5 & 11 \\
\hline Bułgaria & 11,5 & 11,3 & 11,6 & b.d. & b.d. \\
\hline Austria & 12,8 & 13,2 & 12,4 & 11 & 19 \\
\hline Francja & 12,9 & 13,4 & 12,4 & 7 & 13 \\
\hline Szwecja & 12,9 & 13,1 & 12,6 & 7 & 17 \\
\hline Dania & 13,4 & 13,1 & 13,7 & 8 & 10 \\
\hline Belgia & 13,8 & 14,4 & 13,1 & 9 & 15 \\
\hline Niemcy & 14,7 & 13,8 & 15,7 & 10 & 18 \\
\hline Portugalia & 15,4 & 16,1 & 14,6 & 15 & 19 \\
\hline Cypr & 15,6 & 14,5 & 16,7 & b.d. & b.d. \\
\hline Finlandia & 15,6 & 15,5 & 15,7 & 11 & 17 \\
\hline Polska & 15,8 & 15,2 & 16,6 & 10 & 17 \\
\hline Hiszpania & 16,0 & 14,7 & 17,3 & 12 & 19 \\
\hline UE & 16,6 & 16,6 & 16,5 & 10 & 17 \\
\hline Słowenia & 16,8 & 16,3 & 17,3 & 13 & 23 \\
\hline Estonia & 16,9 & 16,8 & 17,0 & 9 & 16 \\
\hline Łotwa & 16,9 & 20,9 & 12,0 & 7 & 13 \\
\hline Słowacja & 16,9 & 16,7 & 17,1 & 7 & 15 \\
\hline Grecja & 17,3 & 17,3 & 17,3 & 13 & 28 \\
\hline Litwa & 19,7 & 19,2 & 20,6 & 5 & 13 \\
\hline Czechy & 21,0 & 21,0 & 21,0 & 10 & 19 \\
\hline Luksemburg & 22,5 & 21,0 & 23,6 & 12 & 22 \\
\hline Malta & 22,9 & 21,1 & 24,7 & b.d. & b.d. \\
\hline Irlandia & 23,0 & 24,0 & 22,0 & 12 & 16 \\
\hline Wielka Brytania & 26,1 & 26,1 & 26,2 & 11 & 12 \\
\hline Węgry & 28,5 & 30,4 & 26,3 & 11 & 19 \\
\hline
\end{tabular}

Źródło: Health at a Glance: Europe 2012, OECD Publishing, Paris 2012, s. 53, 63.

odsetek otyłych mężczyzn wynosi 55,7\%9. Te skrajne przypadki to niewielkie kraje, jeszcze do niedawna uchodzące za ubogie, gdzie otyłość była zjawiskiem praktycz-

${ }^{9}$ International Association for the Study of Obesity, www.iaso.org [dostęp: 12.08.2013]. 
nie nieznanym. Sytuację diametralnie zmieniło odkrycie na ich terenach cennych surowców naturalnych. Eksploracja złóż znacznie podniosła ogólny poziom życia. Dieta przeciętnego mieszkańca praktycznie z dnia na dzień stała się dużo bardziej kaloryczna. Bardzo szybko zmienił się także styl życia, możliwe stało się bowiem zaniechanie wykonywania ciężkich prac fizycznych, które wcześniej zapewniały dochód i umożliwiały egzystencję ${ }^{10}$.

Jeśli chodzi o Unię Europejską, to ponad połowa (52\%) jej mieszkańców ma problemy z nadwagą, z czego otyłych jest 16,6\%. Należy w tym miejscu zaznaczyć, że kraje UE są mocno zróżnicowane pod względem częstotliwości występowania osób otyłych: ich udział w społeczeństwie waha się od 7,9\% w Rumunii do 28,5\% na Węgrzech (por. tab. 1). Jeśli chodzi o sytuację w Polsce, to nie jest ona bardzo zła. Odsetek osób otyłych jest nieznacznie mniejszy niż średnia unijna i wynosi 15,5\%. Zdecydowanie niepokoić może natomiast fakt, że w Polsce gwałtownie rozprzestrzenia się problemu otyłości wśród ludzi młodych. W ciągu niespełna jednej dekady odsetek otyłych piętnastolatków zwiększył się aż dwukrotnie, z poziomu 7\% w okresie 2001-2002 r. do poziomu 14\% w okresie 2009-2010 r. ${ }^{11}$

\section{Uwarunkowania epidemii otyłości}

Nie można wyróżnić jednej, uniwersalnej przyczyny rozprzestrzeniania się otyłości. Najogólniej rzecz ujmując, można stwierdzić, że jest to efekt różnorodnych przeobrażeń społecznych i ekonomicznych, które prowadzą do wyraźnego zachwiania równowagi pomiędzy ilością energii, jaką jednostki pobierają, a ilością energii, jaką te jednostki wydatkują.

Obniżenie ilości wydatkowanej energii związane jest przede wszystkim z rozwojem technologicznym, który zasadniczo zmienia styl życia ludności, a zwłaszcza dwie podstawowe sfery życia: pracę i odpoczynek. Dzięki nowoczesnym technologiom (komputerom, robotom) praca zawodowa w coraz mniejszym stopniu wymaga wysiłku fizycznego, a w coraz większym stopniu wymaga wysiłku intelektualnego. Środki do życia zdobywane są bardziej poprzez aktywność umysłową aniżeli fizyczną. Odpoczynek z kolei ma bierny charakter. Coraz większy udział w dobowym rozkładzie zajęć przypada na użytkowanie komputera i oglądanie telewizji. Istotna jest również zmiana w zakresie transportu (upowszechnienie samochodów, rozwój transportu publicznego), która upowszechniła „,siedzący” sposób przemieszczania się.

Zwiększenie ilości pobieranej energii związane jest przede wszystkim z rozwojem społeczno-gospodarczym oraz procesem urbanizacji. Rozwój społeczno-gospodarczy spowodował ogólny wzrost poziomu życia. Żywność, dotychczas ograniczona, stała się relatywnie łatwo dostępna dla praktycznie każdego członka społeczeństwa. Wzrost dostępności pociągnął za sobą zwiększenie ilości pożywienia konsumowanego

${ }^{10}$ Por. M. Konarzewski, Ewolucja otyłości, „Nauka” 2006, nr 4, s. 91.

${ }^{11}$ Health at a Glance: Europe 2012, OECD Publishing, Paris 2012, s. 53. 
per capita ${ }^{12}$. Z kolei migracja ludności ze wsi do miast spowodowała zmianę diety i nawyków żywieniowych. W miastach produkty rolno-spożywcze, takie jak np. świeże owoce czy warzywa, są z reguły mniej dostępne, a tym samym ich ceny są dużo wyższe niż na wsi. Ich miejsce zajmuje przetworzona żywność o dużej zawartości energetycznej (bogata w tłuszcze i cukier). Wzrasta zatem spożycie produktów wysokokalorycznych, które skutecznie zaspokajają głód, a ponadto mają przyjemny smak i są relatywnie tanie ${ }^{13}$.

Spośród potencjalnych przyczyn epidemii otyłości wymienić należy również uwarunkowania genetyczne. Odwołując się do hipotezy oszczędnego genotypu (thrifty gene hypothesis), należy stwierdzić, że otyłość jest charakterystyczna dla tych członków społeczeństw, których przodkowie doświadczali cyklicznych klęsk głodu. Organizm tych ludzi wykształcił w procesie ewolucji specyficzny typ metabolizmu, który umożliwiał kumulowanie zasobów (tłuszczu) w okresie względnej obfitości i wykorzystywanie ich w okresie niedoboru żywności ${ }^{14}$. W czasach współczesnych ludzie mają zapewniony stały dostęp do pożywienia, mimo to „oszczędny genotyp” wciąż przygotowuje ich organizmy do klęski głodu, czego efektem jest chroniczna otyłość.

Omawiając przyczyny otyłości, nie można również pominąć uwarunkowań kulturowych. W niektórych krajach (np. w RPA) nadwaga jest czymś pożądanym. Po pierwsze, jest ona oznaką prestiżu oraz bogactwa. Po drugie, osoby otyłe są uważane za atrakcyjne fizycznie ${ }^{15}$.

\section{Otyłość jako problem zdrowotny, społeczny i ekonomiczny}

Otyłość generuje wiele negatywnych konsekwencji. Przede wszystkim podnosi ona prawdopodobieństwo zapadnięcia na różne schorzenia, takie jak: nadciśnienie, wysoki poziom cholesterolu, cukrzyca, choroby układu krążenia, schorzenia układu oddechowego (astma), cukrzyca, choroby układu mięśniowo-szkieletowego, niektóre formy nowotworów ${ }^{16}$. Przyczynia się ona także do zwiększonej śmiertelności. Szacuje się, że przeciętna długość życia osoby otyłej jest średnio o 8-10 lat krótsza niż osoby o prawidłowym wskaźniki BMI ${ }^{17}$. Istotne są także negatywne konsekwencje

${ }^{12}$ E. Finkelstein, Ch. Ruhm, K. Kosa, Economic causes and consequences of obesity, "Annual Review of Public Health" 2005, nr 26, s. 245.

${ }^{13}$ M. Pena, J. Bacallao, Obesity Among the Poor: an Emerging Problem in Latin America and the Caribbean, [w:] M. Pena, J. Bacallao (red.), Obesity and Poverty. A New Public Health Challenge, Pan American Health Organization, Washington D.C. 2000, s. 8-9.

${ }^{14}$ M. Konarzewski, Na początku był głód, Państwowy Instytut Wydawniczy, Warszawa 2005, s. $120-126$.

${ }^{15}$ Fat is bad but beautiful, "The Economist", 17.12.2011, s. 70.

${ }^{16}$ Health at a Glance: Europe 2012..., s. 62; L. Kłosiewicz-Latoszek, Otyłość jako problem społeczny, zdrowotny i leczniczy, „Problemy Higieny i Epidemiologii” 2010, nr 91(3), s. 339.

${ }^{17}$ Obesity Update 2012, OECD, s. 1, www.oecd.org/health/49716427.pdf [dostęp: 19.01.2014]. 
natury psychologicznej i społecznej. Osoby otyłe obarczone są relatywnie wysokim ryzykiem niskiej samooceny i depresji, a także stygmatyzacji i dyskryminacji ${ }^{18}$.

Otyłość generuje wiele negatywnych konsekwencji ekonomicznych. Przede wszystkim osoby otyłe w większym stopniu niż osoby nieotyłe korzystają ze świadczeń medycznych: częściej udzielane są im porady lekarskie, zażywają więcej leków, więcej dni (w ciągu roku) spędzają w szpitalach ${ }^{19}$. Rozpowszechnianie otyłości nieuchronnie prowadzi zatem do wzrostu wydatków publicznych ponoszonych na służbę zdrowia ${ }^{20}$. Koszty otyłości mają także inny, niemedyczny (pośredni) charakter. Związane są one przede wszystkim ze zwiększoną absencją chorobową i zmniejszoną produktywnością osób otyłych ${ }^{21}$.

W krajach wysoko rozwiniętych wyraźna jest negatywna korelacja pomiędzy otyłością a różnymi wyznacznikami statusu społecznego (wykształcenie, osiągany dochód). Im wyższy status społeczny, tym mniejsze prawdopodobieństwo bycia otyłym. Trudno jest jednoznacznie określić, co jest przyczyną, a co skutkiem takiej zależności. Czy ludzie są otyli dlatego, że są biedni? Czy raczej odwrotnie: są biedni dlatego, że są otyli? Obie opcje są równie prawdopodobne. $Z$ jednej strony ludzie są otyli dlatego, że osiągają niskie dochody, a to z kolei pociąga za sobą konieczność spożywania taniego, wysokoprzetworzonego (kalorycznego) jedzenia. Niski dochód ogranicza także dostęp do płatnych usług sportowych i rekreacyjnych, które - jak powszechnie wiadomo - pomagają w utrzymaniu szczupłej sylwetki. $Z$ drugiej strony otyłość „wpędza” w ubóstwo, ponieważ osoby otyłe często są dyskryminowane na rynku pracy ${ }^{22}$. $Z$ reguły mają one mniejsze szanse (niż osoby szczupłe) na zatrudnienie, a jeżeli już zostaną zatrudnione, to zwykle osiągają niższe dochody i mają mniejsze szanse na awans zawodowy ${ }^{23}$.

${ }^{18}$ J. Cawley, Introduction, [w:] J. Cawley (red.), The Oxford handbook of the Social Science of Obesity, Oxford University Press, New York 2011, s. 1.

${ }^{19} \mathrm{~W}$ literaturze przedmiotu często podkreśla się jednak, że w ogólnym rozrachunku zachowywane jest status quo, co związane jest z krótszym trwaniem życia osób otyłych, a dokładniej z krótszym czasem, jaki przeżywają oni na emeryturze. Inaczej rzecz ujmując, wyższe wydatki publiczne na opiekę medyczną rekompensowane są niższymi wydatkami publicznymi na świadczenia emerytalne. Por. m.in. E. Finkelstein, Ch. Ruhm, K. Kosa, wyd. cyt., s. 247.

${ }^{20}$ I. Rashad, M. Grossman, The economics of obesity, „Public Interest” 2004, nr 156, s. 110.

${ }^{21}$ I. Caterson, J. Franklin, G. Coldditz, Economic Costs of Obesity, [w:] G. Bray, C. Bouchard (red.), Obesity. Etiology and Pathophysiology, Marcel Dekker, New York 2005, s. 150.

${ }^{22}$ Wśród specjalistów ds. HR można spotkać się z opinią, jakoby otyłość była przejawem negatywnych cech charakteru (takich jak np. brak samodyscypliny i konsekwencji), które zdecydowanie nie są pożądane wśród pracodawców. Uważa się, że jeżeli ktoś nie jest w stanie należycie zadbać o swój organizm, to prawdopodobnie nie będzie również w stanie należycie realizować powierzonych mu zadań zawodowych.

${ }^{23}$ R. Puhl, Ch. Heuer, K. Brownell, Stigma and Social Consequences of Obesity, [w:] P. Kopelman, I. Caterson, W. Dietz (red), Clinical Obesity in Adults and Children, Wiley-Blackwell, Oxford 2010, s. 27-28. 


\section{Działania wobec problemu otyłości: perspektywa ponadnarodowa}

Głównym podmiotem międzynarodowym zaangażowanym w walkę z otyłością jest Światowa Organizacja Zdrowia (WHO). W 2004 r. (podczas 57. Światowego Zgromadzenia Zdrowia) przyjęła ona Globalna strategię dotycząca żywienia, aktywności fizycznej $i$ zdrowia (ang. Global Strategy on Diet, Physical Activity and Health). W dokumencie tym wezwano rządy krajów członkowskich, podmioty komercyjne i pozarządowe, a także pozostałych interesariuszy do rozwijania i wdrażania działań na rzecz poprawy stanu zdrowia ludności poprzez zdrowe żywienie i wzrost aktywności fizycznej. Globalna strategia oparta została na 4 głównych celach. Pierwszy z nich to ograniczenie czynników ryzyka chronicznej otyłości, czyli niezdrowego żywienia i ograniczonej aktywności fizycznej. Drugi cel to zwiększenie świadomości społecznej w zakresie pozytywnego wpływu diety i ćwiczeń na dobrostan fizyczny. Trzeci cel to rozwijanie i wdrażanie globalnych, krajowych i regionalnych programów działań na rzecz walki z otyłością. Czwarty cel to rozwój i promowanie badań naukowych poświęconych przeciwdziałaniu i leczeniu otyłości.

Pod wpływem Globalnej strategii przedstawiciele 46 krajów regionu europejskiego WHO podpisali w 2006 r. Europejska karte przeciwdziałania otyłości (European Charter on Counteracting Obesity). Sygnatariusze tego dokumentu (w tym Polska) zadeklarowali wzrost zaangażowania w zwalczanie otyłości, a także nadanie tej kwestii wysokiego priorytetu w programach rządowych. Zaznaczono, że walka z otyłością wymaga kompleksowego (systemowego) podejścia do problemu i zaangażowania różnych podmiotów: administracji publicznej, organizacji społecznych, mediów, przedsiębiorców. Stwierdzono ponadto, że współpraca międzysektorowa powinna być nawiązywana nie tylko na poziomie krajowym, ale również (przede wszystkim) na poziomie międzynarodowym, przy współudziale takich organizacji, jak: Światowa Organizacja Zdrowia (WHO), Organizacja Narodów Zjednoczonych ds. Wyżywienia i Rolnictwa (FAO), Międzynarodowy Fundusz Narodów Zjednoczonych Pomocy Dzieciom (UNICEF), Bank Światowy, Rada Europy, Międzynarodowa Organizacja Pracy (MOP), a także Organizacja Współpracy Gospodarczej i Rozwoju (OECD).

W 2007 r. Komisja Europejska przyjęła dokument zatytułowany Biała Księga: Europejska strategia na rzecz problemów zdrowotnych związanych z odżywianiem się, nadwaga i otylościa (White Paper on a Strategy for Europe on Nutrition, Overweight and Obesity Related Health Issues). Przedstawiono tam długofalowy plan działań, które docelowo mają ograniczyć skalę otyłości w Unii Europejskiej. Główne cele, jakie zostały określone w strategii, to:

(1) „Lepiej poinformowany konsument”: wpływanie na wiedzę, preferencje i zachowania w zakresie stylu życia i nawyków żywieniowych. $Z$ jednej strony mowa tutaj o zapewnieniu jasnej, spójnej i opartej na faktach informacji, która umożliwia dokonywanie lepszych i bardziej świadomych wyborów konsumenckich. Z drugiej 
strony, chodzi o ogólną politykę informacyjną na temat zdrowego odżywiania się. Konkretnym narzędziem, które powinno zostać zastosowane do realizacji tego celu, jest nakaz umieszczania na opakowaniach informacji o wartości odżywczej, a także specjalne oznakowywanie produktów spożywczych (np. informacja o negatywnym wpływie na stan zdrowia). Jeśli chodzi o politykę informacyjną, to narzędziem realizacji tego celu powinny być kampanie społeczne promujące zdrową żywność i/lub ograniczenie reklamy niezdrowej żywności (zwłaszcza skierowanej do dzieci).

(2) „Stworzenie zdrowej alternatywy”: zwiększenie dostępności zdrowych produktów spożywczych. Realizacji tego celu służą przede wszystkim narzędzia fiskalne. Umożliwiają one obniżanie cen zdrowej żywności (poprzez preferencyjne stawki podatkowe) i/lub podnoszenie cen niezdrowej żywności (poprzez wyższe stawki podatkowe lub narzucanie specjalnych podatków, takich jak np. ,,podatek thuszczowy” w Danii czy „podatek chipsowy” na Węgrzech). Innym narzędziem realizacji tego celu jest przekazywanie nadwyżek produkcji zdrowej żywności (owoców, warzyw, soków) do instytucji edukacyjnych i ośrodków wypoczynkowych dla dzieci. Kolejną ważną kwestią jest zmiana składu produktów spożywczych na bardziej prozdrowotny.

(3) „Wspieranie aktywności fizycznej”: tworzenie środowiska fizycznego i społecznego wspierającego zwiększanie aktywności fizycznej. Narzędziem realizacji tego celu powinna być promocja sportu i aktywnego odpoczynku, rozwój infrastruktury publicznej ułatwiającej przemieszczanie się pieszo i/lub na rowerze (tzw. zrównoważony transport miejski").

(4) „Grupy priorytetowe”: skoncentrowanie działań przede wszystkim na dwóch grupach najbardziej narażonych na ryzyko otyłości: na dzieciach oraz na osobach ubogich. Narzędziem realizacji tego celu, jeśli chodzi o dzieci, jest edukacja zdrowotna i fizyczna. Jeśli chodzi zaś o osoby ubogie, to realizacji celu powinny służyć różnego rodzaju narzędzia socjalne.

(5) „Rozwój badań naukowych w celu skuteczniejszego kreowania działań politycznych": poszerzenie wiedzy na temat czynników wpływających na zachowania konsumenckie, wpływu odżywania na zdrowie oraz czynników zapobiegających nadwadze.

(6) „Rozwijanie systemów monitorowania”: gromadzenie danych na temat wskaźników otyłości i nadwagi, które byłyby porównywalne w skali międzynarodowej; analiza działań podejmowanych przez kraje członkowskie i ocena ich skutków.

\section{Zakończenie}

Współcześnie otyłość staje się coraz bardziej powszechnym elementem otaczającej nas rzeczywistości. Wzrost liczby i odsetka ludzi otyłych prowadzi do wielu negatywnych konsekwencji natury zdrowotnej, społecznej i ekonomicznej. Najważniejsze z nich to: wzrost zapadalności na różne schorzenia, skrócenie trwania życia, zwiększenie wydatków publicznych ponoszonych na służbę zdrowia, upowszech- 
nienie negatywnych postaw wobec osób otyłych i obniżenie ich jakości życia. Duża skala i drażliwe konsekwencje spowodowały, że otyłość przestała być problemem indywidualnym, a stała się kwestią społeczną. Stworzyła się tym samym przestrzeń do ingerencji ze strony władz publicznych i organizacji pozarządowych.

Problem otyłości jest dość złożony i w związku z tym walka z nim wymaga podjęcia dość złożonych działań. Inicjatywy w tym zakresie, aby były skuteczne, muszą być spójne. Przede wszystkim istotna jest komplementarność pozioma, co oznacza, że działania powinny być realizowane $\mathrm{w}$ ramach różnych polityk, $w$ tym przede wszystkim: polityki edukacyjnej (włączenie zagadnień z zakresu zdrowego odżywiania się do programu nauczania, rozwój zajęć sportowych), polityki zdrowotnej (prewencja i leczenie otyłości), polityki transportowej i urbanistycznej (rozwój infrastruktury sportowo-rekreacyjnej), polityki informacyjnej (promocja aktywności fizycznej, informowanie na temat przyczyn i skutków otyłości, ograniczenie reklam niezdrowej żywności wśród dzieci), polityki fiskalnej (ingerowanie - poprzez system podatkowy - w ceny poszczególnych typów żywności). Ważna jest ponadto komplementarność pionowa, co oznacza, że działania powinny być podejmowane na różnych poziomach działania: w skali lokalnej, regionalnej, ogólnokrajowej i ponadnarodowej.

\section{Literatura}

Biała Księga: Europejska strategia na rzecz problemów zdrowotnych zwiąanych z odżywianiem się, nadwagą i otyłością, dokument Komisji Europejskiej, 2007.

Caterson I., Franklin J., Coldditz G., Economic Costs of Obesity, [w:] G. Bray, C. Bouchard (red.), Obesity. Etiology and Pathophysiology, Marcel Dekker, New York 2005.

Cawley J., Introduction, [w:] J. Cawley (red.), The Oxford Handbook of the Social Science of Obesity, Oxford University Press, New York 2011.

Europejska Karta Przeciwdziałania Otyłości, dokument WHO, 2006.

Fat is bad but beautiful, "The Economist", 17.12.2011.

Finkelstein E., Ruhm Ch., Kosa K., Economic causes and consequences of obesity, "Annual Review of Public Health" 2005, nr 26.

Fogel R., Costa D., A theory of technophysio evolution, with some implication for forecasting population, health care, and pension costs, „Demography” 1997, $\mathrm{nr} 34$.

Globalna strategia dotycząca żywienia, aktywności fizycznej i zdrowia, dokument WHO, 2004.

Głód i niedożywienie dzieci w Polsce - raport z badania ilościowego, luty 2013 r., Polska Fundacja

Pomocy Dzieciom „Maciuś”, www.pfpd.org/wp-content/uploads/2013/03/Analiza-fundacji.pdf.

Guillén M.F., Ontiveros E., Global Turning Points. Understanding the Challenges for Business in the $21^{\text {st }}$ Century, Cambridge University Press, New York 2012.

Health at a Glance: Europe 2012, OECD Publishing, Paris 2012.

International Association for the Study of Obesity, www.iaso.org.

Kłosiewicz-Latoszek L., Otyłość jako problem społeczny, zdrowotny i leczniczy, „Problemy Higieny i Epidemiologii” 2010, nr 91(3).

Konarzewski M., Ewolucja otyłości, „Nauka” 2006, nr 4.

Konarzewski M., Na początku był głód, Państwowy Instytut Wydawniczy, Warszawa 2005.

Miech R.A., Kumanyika S.K., Stettler N., Link B.G., Phelan J.C., Change V.W., Trends in the association of poverty with overweight among US adolescents, 1971-2004, "JAMA" 2006, nr 295.

Obesity Update 2012, OECD, s. 1, www.oecd.org/health/49716427.pdf. 
OECD Health Data 2011, http://dx.doi.org/10.1787/888932523956.

Osiecka-Chojnacka J., Epidemia otyłości a interwencja władz publicznych, „Infos: zagadnienia społeczno-gospodarcze", nr 3(17), Biuro Analiz Sejmowych, Warszawa 2012.

Panek T., Czapiński J., Wyżywienie, [w:] J. Czapiński, T. Panek (red.), Diagnoza społeczna, Rada Monitoringu Społecznego, Warszawa 2013.

Pena M., Bacallao J., Obesity Among the Poor: an Emerging Problem in Latin America and the Caribbean, [w:] M. Pena, J. Bacallao (red.), Obesity and Poverty. A New Public Health Challenge, Pan American Health Organization, Washington D.C. 2000.

Puhl R., Heuer Ch., Brownell K., Stigma and Social Consequences of Obesity, [w:] P. Kopelman, I. Caterson, W. Dietz (red.), Clinical Obesity in Adults and Children, Wiley-Blackwell, Oxford 2010.

Rashad I., Grossman M., The economics of obesity, „Public Interest” 2004, nr 156.

Sauvy A., Granice życia ludzkiego, PWN, Warszawa 1963.

Szymocha M., Bryła M., Maniecka-Bryła I., Epidemia otyłości w XXI wieku, „Zdrowie Publiczne” 2009, nr 119(2).

\section{OBESITY AS A CHALLENGE FOR THE SOCIAL POLICY IN THE 21 ${ }^{\text {ST }}$ CENTURY}

Summary: Nowadays we can see a fundamental change in social reality. A traditional problem of starvation steadily disappears, and on its place there is a new problem, which is obesity. Today obesity is a global social issue. The scale of the problem has become so large that World Health Organization (WHO) began to talk about the worldwide obesity epidemic. The main objective of the article is to present obesity as one of the most important challenges for the modern social policy. We will try to find the answer for the following questions: What is the essence and prevalence of obesity? What are the socio-economic consequences of obesity? What actions are taken to reduce obesity? The article uses the following research methods: literature review, legislative research and the analysis of statistical data.

Keywords: famine, obesity, social policy, poverty. 